\title{
LEXICAL ITEMS IN BATAK TOBA LANGUAGE REPRESENTING FAUNA, FLORA, AND SOCIAL ENVIRONMENT: ECOLINGUISTICS STUDY
}

\author{
Mery Silalahi \\ Universitas Sari Mutiara Indonesia \\ Email: mery.silalahi@yahoo.com
}

\begin{abstract}
In ecolinguistic perspective, the relationship between human and nature (ecology) produces a variety of languages (linguistics). Language and environment are two things that influence each other. Change in language, both in the lexicon or grammar, cannot be released from changes in the natural and social environment. On the one hand, environmental changes have an impact on change in language, and on the other hand, the community behavior towards their environment influenced by the language they use. Thus, the dynamics of the existence of the lexicon are affected by changes in the environment of a place the language used. The results of this study prove that there is relationship between language and nature. There are 6 lexicons which be explained in this article. Horbou or buffallo and Dekke or fish: goldfish are lexical items representing fauna. Boras Sipir ni Tondi or Rice and Demban or Sirih or betel leaf are lexical items representing flora. And to the lexical items which representing social environment are Ulos or Woven Cloth and Tortor or Traditional Dance. The six lexical items which are representing natural (two for fauna and flora respectively) and social environment (two lexical items) contain cultural terms in Batak Toba language. Because it is a cultural term, then it cannot be separated from the history of Batak people. The cutural terms then will be analyzed and compared to the present life in Indonesian culture in general. It could have similarities or even differences to the present life in Indonesia.
\end{abstract}

Keywords: Ecolinguistics, Bataknese Language, Lexical Items

\begin{abstract}
ABSTRAK
Dalam perspektif ekolinguistik, hubungan antara manusia dan alam (ekologi) menghasilkan berbagai bahasa (linguistik). Bahasa dan lingkungan adalah dua hal yang saling mempengaruhi. Perubahan dalam bahasa, baik dalam leksikon atau tata bahasa, tidak terlepas dari perubahan dalam lingkungan alam dan sosial. Di satu sisi, perubahan lingkungan berdampak pada perubahan bahasa, dan di sisi lain, perilaku masyarakat terhadap lingkungan dipengaruhi oleh bahasa yang mereka gunakan. Dengan demikian, dinamika keberadaan leksikon dipengaruhi oleh perubahan lingkungan tempat bahasa yang digunakan. Hasil penelitian ini membuktikan bahwa ada hubungan antara bahasa dan alam. Ada 6 leksikon yang dijelaskan dalam artikel ini. Horbou atau Buffallo dan Dekke atau ikan: ikan mas adalah unit leksikal yang mewakili fauna. Boras Sipir ni Tondi atau Beras dan Demban atau Sirih atau daun sirih adalah unit leksikal yang mewakili flora. Unit leksikal yang mewakili lingkungan sosial adalah Ulos atau Kain Tenun dan Tortor atau Tari Tradisional. Enam unit leksikal yang mewakili alam (masing-masing dua untuk fauna dan flora) dan lingkungan sosial (dua unit leksikal) mengandung istilah budaya dalam bahasa Batak Toba. Kajian ini berupa istilah budaya, maka tidak dapat dipisahkan dari sejarah orang Batak. Istilah budaya kemudian akan dianalisis dan dibandingkan dengan kehidupan sekarang dalam budaya Indonesia secara umum. Bisa memiliki kesamaan bahkan perbedaan dengan kehidupan sekarang di Indonesia.
\end{abstract}

Kata kunci: Ekolinguistik, Bahasa Batak, unit leksikal 


\section{INTRODUCTION}

Ecolinguistic studies which were initially named as studies of language ecology, are new paradigms relating to the ecological and linguistic relationships initiated by Einar Haugen in 1970. This study compares language studies with ecology which can be defined as a study of the interaction between languages and their environment or the environment in which the language is used. The relationship between human and nature (ecology) produces a variety of languages (linguistics). Halliday (2001) explained that language and environment are two inseparable things that influence each other. The changes in language, both in lexicon or grammar are integrated from the changes occurred in the natural and social environment. On the one hand, environmental changes have an impact on change in language, and on the other hand, the community attitudes towards their environment are affected by the language they use. Thus, the dynamics of lexicon are affected by changes in the environmental condition in which a language is used.

According to Kridalaksana (1982), the lexicon is a list of words about the natural environment which is accompanied by an explanation and refers to the richness of one's vocabulary mastery. This article focusses on the lexicons which refer to Bataknese culture. Bataknese is extraordinarily rich for its lexicons to refer their natural environment of both flora and fauna entities. This article explores some lexical items which represent the nature (two for fauna and flora respectively) and social environment (two lexical items) in Batak Toba language. With regard to this, this phenomena needs to be observed from the ecolinguistic perspective, which is aimed to examine the interrelationships between nature/ environment with language or juxtaposing ecology and linguistics. As scientific discipline, ecology explains reciprocal relationships between human beings with the natural surroundings.

There are 6 lexicons that are going to be explained in this article. Horbou or buffallo and Dekke or fish: goldfish, all of which represent fauna. Boras Sipir ni Tondi or Rice and Demban or betel leaf are lexical items representing flora. Additionally to the lexical items which represent social environment, such as Ulos or Woven Cloth and Tortor or Traditional Dance. Then those cutural terms will be analyzed and compared to current lives in Indonesian culture extensively. Theoretically, ecolinguistic studies may belong to environmental studies that adapt linguistic perspective. This is so because the socio-ecological changes greatly affect people's use of language and changes in cultural values of a society (Al Gayoni, 2010: 1). 


\section{THEORETICAL FRAMEWORK}

Language change, especially on lexicon level is inseparable from changes in the natural environment because the language and environment are two things that influence each other. This phenomenon is an area of ecolinguistic studies, namely a discipline that studies language and environment and juxtaposing ecology with linguistics (Mbete, 2008:1). The idea of ecology of language in sociolinguistic studies actually it was alluded to by Gumperz (1962). Gumperz (1962: 137) argue that sociolinguistics is study of verbal attitudes related to speakers' social characteristics, their cultural background, and the ecological nature of the environment as a place of interaction. Thus, ecolinguistics is defined as interaction between language and environment used by speaker of a language.

In 1970, Haugen for the first time introduced the term ecology of language (1972: 325, in Fill and Mühlhäusler, 2001: 57). Haugen explained that "ecology of language may be defined as the study of interactions between any given language and its environment". Haugen confirmed that language is in the user's mind and language functions in relationships between users and its environment, that are social environment and natural environment. According to Haugen (in Dil, 1972: 325--329), defines language environment as follows: "The true environment of a language is the society that uses it as one of its codes. Language exists only in the minds of its speaker, and it only functions in relating the users to one another to nature, i.e. their social natural environment. The ecology of a language is determined primely by those who learn it, use it, and transmit it to others.

Haugen's statement implies that the environment of a language is basic language in the form of a social setting and cultural setting, not just a physical setting for it is impossible to understand a thing language without speakers. The change or shift and survival of a language (especially at the lexicon level) is influenced by environmental changes including the nature, social, and culture that hit the language environment. It will be happened in one language that lives in the middle of one community, also be changed, because of modernization and globalization. Changes that hit social and cultural aspects also influence the use of language, especially in lexicon level.

There are several linguists who put forward the concept of the lexicon with various emphases. One of the other linguists is Spencer (1993: 47) who states:

"The term lexicon means simply dictionary is a list of words together with their meaning and other useful bits of linguistic information..." 
The statement above implies that the lexicon is a list of words that have little meaning accompanied by information relating to linguistic information. El-son and Pickett (1987: 1) define lexicon as the vocabulary of a language or vocabulary owned by a language speaker, or the total number of morphemes or words of a language. The words intended by Elson and Picket (1987) are not words that only have separate meanings, but meanings that are influenced by the context of the situation, the words that accompany it, their position in the grammatical pattern, and the way they are used social. Meanwhile, Martin Haspelmath (2002: 39) describes the lexicon as a term that refers to mental dictionaries and grammatical rules about the language that speakers of a language must possess. In addition, Crystal (1985: 78) says that the lexicon is a component that contains information about word traits in a language, such as semantic behavior, syntactic, and phonological. In the Indonesian Big Dictionary (Depdiknas, 2008: 805) it is stated that the lexicon is a vocabulary; language component that contains all information about the meaning and usage of words in language; the wealth of words that a language has.

Based on the lexicon concepts described above, the lexicon concept proposed by Kridalaksana (1982) is applied in this study because the lexicon referred to in this study is a list of words about the natural environment accompanied by an explanation and refers to wealth. the word someone has, in this case research respondents.

\section{RESEARCH METHODS}

This study was designed with qualitative research approach. Djajasudarma (2006: 11) suggests that a qualitative approach is a procedure that produces descriptive data in the form of written or oral data. This is because the qualitative approach prioritizes data analysis techniques with the power of in-depth descriptions.

The data obtained from this study is the six lexical items representing natural (two for fauna and flora respectively) and social environment (two lexical items) in Batak Toba language. Horbou or buffallo and Dekke or fish: goldfish are lexical items representing fauna. Boras Sipir ni Tondi or Rice and Demban or Sirih or betel leaf are lexical items representing flora. And to the lexical items which representing social environment are Ulos or Woven Cloth and Tortor or Traditional Dance. Then, those six lexical items will be analyzed and compared to the present life in Indonesian culture in general. It could have similarities or even differences to the present life in Indonesia. All those will be explained in this chapter. 


\section{FINDING AND DISCUSSION}

In this article, there are six lexical items representing natural (two for fauna and flora respectively) and social environment (two lexical items) in Batak Toba language. Horbou or buffallo and Dekke or fish: goldfish are lexical items representing fauna. Boras Sipir ni Tondi or Rice and Demban or Sirih or betel leaf are lexical items representing flora. And to the lexical items which representing social environment are Ulos or Woven Cloth and Tortor or Traditional Dance. The descriptions of the six lexical items will be shown as follow:

\section{Representing Fauna}

\section{Horbou or buffallo}

Horbou or buffallo has become one of the animals that have a high degree in the social life of Batak culture. Not only to be consumed, the animal's organs are used as art ornaments on traditional Batak houses. Batak ornaments on the Batak community are a symbol that has a sacred. Its sacred nature is known through the buffalo ornaments on megalithic remains associated with the gravestone, is the symbol of the vehicle (rides) for the soul to the spirit world. Buffalo ornaments also symbolize fertility associated with the livelihood of megalithic supporters of livelihoods in agriculture. In addition, buffalo ornaments are often depicted in traditional houses Batak community in North Sumatra. Batak admits that buffalo is a sacrificial animal that has the highest value compared to other animals such as pigs. A buffalo slaughtered at a traditional ceremony, describing the ability of the family or the high social status of a person in society. It is symbolically reflected on the number of buffalo horns on display at traditional houses. Ownership of a buffalo signifies the prestige of a person; the rich and high status of a person is marked how many buffalo he has.

For Bataknese, the following is the philosophy of a buffalo:

- Considered as the richest animal of all pets; has two horns, four centers, and is very mighty.

- Having a pair of buffalo horns which is a symbol of the descent of two ancestors of the Batak people, namely Lontung and Sumba.

- Buffalo always faithful to help humans, such as plowing rice fields, for agricultural products abundant.

\section{Dekke or fish: goldfish}


according to Batak, ikan mas (goldfish) is dekke sitio-tio and dekke simudurudur. This fish symbolizes the purity of life and longevity. This meaning can be seen from the habitat of goldfish that live in fresh water and have a long body. This fish also symbolizes the peaceful life of hereditary as well as goldfish that live in clusters (marudur-udur). In the Batak community, this fish will then be processed into a dish which is then referred as dekke na ni arsik. This dish has a strong tradition value. Dekke na ni arsik is a media offering for the ancestors and family members who have died. Not only that, dekke na ni arsik is also a form of expression of gratitude to God Almighty.

\section{Representing Flora}

\section{Boras Sipir ni Tondi or Rice}

For Batak people, rice is one of the symbols commonly used by in Ritual or certain activities. Especially in Indonesia rice is very easy to obtain and found because most of the population work as farmers. The tradition of using rice is called as "Boras Sipir ni Tondi". Tradition Boras Sipir ni Tondi is a tradition of Batak people who have long existed, usually the symbol used is rice. This tradition is usually used in weddings, entering new homes, childbirth events, and blessing people. The purpose of this tradition is to strengthen the soul. The tradition of Boras Sipir ni Tondi has a positive purpose, and people who do this tradition hope that what he said can be answered as well as those who are part of this tradition. And the core of Boras Sipirni Tondi is to strengthen the Soul. And even now the Batak people still maintain this tradition, because they believe in the kindness of this tradition.

\section{Demban or Sirih or betel leaf}

Demban has long been known by the Batak people, even demban is regarded as a magical leaf and until now still used in rituals or in customary ceremonies, especially in marriage, in addition to still generally used as a chewing by mothers in the countryside in Batak Land. Formerly in religious rituals demban used as a base for offerings sesajen which usually with odd amounts are included along with jeruk purut jantan and eggs along with other offerings to Maha Pencipta Mulajadi Nabolon, including medication done by dukun (datu).

At this time demban still included in the marriage customary procedures. In the marriage custom, the delivery of the dowry (sinamot/ tuhor) on demban which is placed on a plate containing rice. To welcome guests and stay in touch with the dish and eat demban (marnapuran) together. Demban mixed with other ingredients, lime, areca nut and gambier. 
Prayer prostration (martonggo) to Ompu Mulajadi Nabolon, with the position of the hand of worship, where the demban is placed on the palm and fingers, the demban folded two covering the top surface of the leaf, the base of the leaf at the fingertips, and the middle bone of the leaves parallel to both indexes.

Demban, though alive by riding on this other plant, does not take the nutrients from the plants it occupies. Even the beautiful leaf-shaped heart will instead beautify the plant that it occupies. Such is the symbol we can learn that portrays peaceful coexistence with extraordinary diversity in our beautiful country. As a symbol of harmony and peace, no wonder in the customs of a particular tribe often brings and or presents this demban as an assertion of harmonious life and not harm each other.

\section{Representing Social Environment Ulos or Woven Cloth}

Ulos is a typical Batak woven cloth shaped scarves. This sacred object is a symbol of blessing, compassion and unity, in accordance with the Batak saying: "Ijuk Pangihot ni hodong, Ulos pangihot ni holong", which means if ijuk is a binding of midrib on the trunk then ulos is a binder of affection between the fellow. Literally, ulos means a blanket that warms the body and protects it from cold air. According to the ancestral beliefs of Batak tribe there are three sources that give heat to humans, namely the sun, fire and ulos. Of these three sources of warmth ulos are considered most comfortable and familiar with everyday life. Formerly the ancestors of the Batak tribe are mountain humans, so the title that is pinned on them. This is due to their habit of living and farming in the mountains. By inhabiting the plateau means they must be ready to fight against the cold weather that pierces the bones. This is where the history of ulos begins.

At first their ancestors relied on sunshine and fire as a shield against coldness. Small problems arise when they realize that the sun cannot be governed according to human desire. During the day clouds and clouds are often unfriendly. While at night the cold is getting worse and fire as an alternative is not very practical to use in sleeping at night for its potential risk. Forced by the urgent necessity of their ancestors, they thought hard to find a more practical alternative. Thus, ulos is dedicated to be a product of Batak tribe's indigenous culture.

Surely ulos did not directly become sacred in the early days of its emergence. In accordance with ulos natural law has also been through a long process that takes a long time, before finally becoming one of the indigenous symbols Batak tribe as it is 
now. In contrast to the sacred ulos we know, ulos used to be used as a blanket or bedding by the ancestors of the Batak tribe. But ulos they use are much higher quality, thicker, softer and with very artistic motifs.

After the start known, ulos increasingly popular because of practical. Unlike the sometimes-stinging sun and sometimes hiding, it is not like a fire that can cause disaster, ulos can be taken anywhere. Gradually ulos become the primary needs, because it can also be used as a beautiful clothing material with interesting motifs. Ulos then has a more important meaning when he began to be used by indigenous elders and village leaders in formal meetings. Coupled with the habit of Batak ancestors who always choose ulos to be a gift or gift to the people they care about.

In mangulosi ritual there are some rules that must be obeyed, among others that one can only mangulosi them which according to speech or genealogy descendants are under, for example, parents may mengulosi child, but child should not mangulosi parent. In addition, the type of ulos given should be in accordance with the customary provisions. Because each ulos has its own meaning, when used, delivered to whom, and in what custom ceremony, therefore, its function can not be exchanged.

Ulos now has a symbolic function for various aspects in all aspects of Batak life. Ulos has been the inseparable symbol from indigenous Batak tribe. Mangulosi, is one of the most important things in Batak custom. Mangulosi literally means giving ulos. Mangulosi is not just a regular gift, since this ritual contains a deep enough meaning. Mangulosi symbolizes the giving of blessings, the outpouring of love, hope and other goodness.

\section{Tortor or Traditional Dance}

Tortor is a traditional dance of Batak Toba tribe that has an important role in indigenous Batak society. The dancers are called panortor. Tortor is a dance, but the deepest meaning of his movement moves indicates that Tortor is a medium of communication (Mauly Purba 1989: 64). Tortor is the art of dance by moving the whole body with a guiding gondang rhythm, with the center of movement on the hands and fingers, legs and soles of feet, back and shoulders. Gondang and Tortor are two things that are not separated like a coin with both sides.

In general, the inheritance of knowledge about something that has existed since the time of the ancestors is an absolute to maintain the tradition or culture. Similarly, the movement of Tortor which at this time has much to remove elements 
of the old tradition of trust. Along with the musical change of gondang tradition from old tradition beliefs into a more secular type of music. In customary events, for example in marriage, the presentation of tortor is freer, though still in the attachment of the element of Dalihan Na Tolu, meaning that the rules in the manortor are still executed even though the value of its sacredness has begun to disappear.

The six lexical items which are representing natural (two for fauna and flora respectively) and social environment (two lexical items) contain cultural terms in Batak Toba language. Because it is a cultural term, then it cannot be separated from the history of Batak people. The cutural terms then will be analyzed and compared to the present life in Indonesian culture in general. It could have similarities or even differences to the present life in Indonesia. All those will be explained in this chapter.

\section{Fauna Representation}

\section{Horbou or buffallo}

Horbou in Batak people with the Buffalo has same meaning. Horbou is animal with its sharp and strong horns. Horbou is used as a means of transportation (vehicle), to help cultivate agricultural land, and the feces can be used as fertilizer (Gunadi, 2000: 60). In the ancient times, buffalo hunted and consumed to meet the needs of human food at that time.

In addition, buffalo has many functions among them as animals that help to cultivate rice fields, milk producers, meat producers, fertilizer producers, and as textile materials (industry).

\section{Dekke or fish: goldfish}

Goldfish is a type of freshwater fish which is economical because its price is not too expensive for all community. And it tastes very delicious. Goldfish contains acid omega 3 fats which can prevent heart disease and heart failure, it also can stimulate brain activity and high growth of children, reduces breast, colon and prostate cancer risk, prevents inflammation of the joints. Nourish the eyes, delay the aging process (wrinkles) and also not easily depressed so that the feeling of excessive fear can be overcome. Therefore, eat lots of fish are beneficial to health. Fish itself has a philosophy of how to deal with life. This fish swim with never backward. Likewise, with life, we must continue to advance against all obstacles.

\section{Flora Representation}

Boras Sipir ni Tondi or Rice. 
Rice is the staple food of the Indonesian people, and rice is also one of the foods that can be processed into other types of food.

\section{Demban or betel leaf}

Demban contains 1-4.2\% essential oil consisting of chavikol, chavibetol, hydroxychavikol, carvakol, eugenol, eugenol methyl ether, p-cymene, cyenole, caryophyllene, cadinese, estragol, terpenes, sesquipermenes, phenyl propane, tannins, diastase, sugar, starch. Chavikol causes demban to have a distinctive and strong anti-bacterial odor, and generally warm, spicy, aromatic, astrigen, stimulant, anti-inflammatory, antiseptic, antibacterial, hemostatic, sedative, laxative, saliva, prevent infection. No doubt avail demban for health.

\section{Social Environment Representation Ulos or Woven Cloth}

This woven cloth is a typical Batak clothing in North Sumatra, its shape resembles a shawl with a length of about 1.8 meters and a width of 1 meter, both ends dangling with a length of about $15 \mathrm{~cm}$ and making Ulos performed by women they weave from cotton yarn or hemp.

The looms include:

Tundalan (Waist Tie)

Turak Baliga (Yarn Split)

Langgiyang (Yard Keeper Tool not to tangle)

Patubobohon (Tool for measuring the length of woven fabric)

In its development, ulos is also given to people "non Batak". This gift can be interpreted as a tribute and affection to the ulos recipient. For example, giving ulos to the President or State Officials, always accompanied by prayer and hope that in carrying out his duties he is always in warmth and affection to the people and the people he leads.

\section{Tortor or Traditional Dance}

Today tortor are performed in church festivities (church building) in order to raise funds or excitement activities (celebration of the great day of Christians) especially the Batak Toba. The most commonly encountered tortor today is the tortor in the Batak Toba wedding party, at the Saurmatua death ceremony, and at the horja party (the inauguration of the monument). Many societies (especially the elderly) claim that the use of tortor has undergone many changes. This is due to the entry of 
Christianity to the Land of Batak, which has made many restrictions on the use of tortor and gondang sabangunan. has been found many shifts or no longer pay attention to the meaning of custom. This can be seen clearly during the ethnic Batak marriage ceremonies where tortor held no longer a medium of communication by noticing the meaning of every symbol of the movements that exist in the tortor, but the tortor is held only into an art that can entertain and enliven the party and there are also which has the purpose of making a profit for the party organizers by showing the bride and groom in the public while dancing tortor (patortor hon parumaen), and then the invitees or people who will join the dance will give some money tucked in the fingers of the organizers and the second bride.

\section{CONCLUSION}

In the ecolinguistic view, the relationship between human and nature (ecology) produces a variety of languages (linguistics). Language and environment are two things that influence each other. Change in language, both in the lexicon or grammar, cannot be released from changes in the natural and social environment. The results of this study prove that there is relationship between language and nature. There are 6 lexicons which be explained in this article. Horbou or buffallo and Dekke or fish: goldfish are lexical items representing fauna. Boras Sipir ni Tondi or Rice and Demban or Sirih or betel leaf are lexical items representing flora. And to the lexical items which representing social environment are Ulos or Woven Cloth and Tortor or Traditional Dance. The six lexical items which are representing natural (two for fauna and flora respectively) and social environment (two lexical items) contain cultural terms in Batak Toba language. Because it is a cultural term, then it cannot be separated from the history of Batak people. The cutural terms then will be analyzed and compared to the present life in Indonesian culture in general. It could have similarities or even differences to the present life in Indonesia. For instance, Horbou or Buffalo not only for Batak people but for all people, has many functions as animal that help to cultivate rice fields, milk producers, meat producers, fertilizer producers, and as textile materials (industry). Then, same to this case, ulos or woven cloth is a typical Batak clothing in North Sumatra. In its development, ulos is also given to people "non Batak". This gift can be interpreted as a tribute and affection to the ulos recipient.

\section{REFERENCES}


Bang, J.Chr. dan Door, J. (1993). Eco- Linguitics: A Framework. [online]. Retrievable from: www.jcbang.dk/main/ecolinguistics/Ecoling_AFramework1993.pdf

Haugen, E. (1972). “The Ecology of Language" in Dil, A.S. (ed). The Ecology of Language: Essays by Einar Haugen. Stanford: Stanford University Press

Halliday, M.A.K. (1990). New Ways of Meaning: The Challenge to Applied Linguistics. Journal of Applied Linguistics, 6, 7-36

Halliday, M.A.K. (2001). "New Ways of Meaning: The Challenge to Applied Linguistics" in Fill, A. dan Muhlhausler, P. The Ecolinguistics Reader: Language, Ecology, and Environment. London: Continuum

Mbete, A.M. (2009). "Refleksi Ringan Tentang Problemantika Keetnikan dan Kebahasaan dalam Perspektif Ekolingistik". Makalah Seminar Nasional Budaya Etnik III, USU Medan, 25 April 2009

Rosidi, A. (2004). Babasan \& Paribasa Kabeungharan Basa Sunda 1, Kiblat Buku Utama, Bandung

Rosidi, A. (2009). Babasan E Paribasa Kabeungharan Basa Sunda 2, Kiblat Buku Utama, Bandung

Subiyanto, A. (2013). Ekolinguistik: model analisis dan penerapannya, [online] Dapat diakses lewat situs: www. portalgaruda.org 